\section{DEPICTION OF POST COLONIALISM IN SOUTH ASIAN CINEMA: A SEMIOTICAL ANALYSIS OF BOLLYWOOD'S FILM PINJAR}

\author{
Hamza Hassan \\ Universiti Malaysia Sarawak
}

\section{Teo Miaw Lee}

Universiti Malaysia Sarawak

Corresponding Author hamzaofficial2000@gmail.com
The concept of Post-colonialism has been broadly used, not only in South Asian society but around the globe to study the relationship between the colonizer and the colonized ones. Like many European and African countries, British ruled the Indian Sub-continent for centuries. The film Pinjar is based on a novel. It portrays the diversity of cultures, creeds, religions and traditions reflecting the era before and during the partition of Indian sub-continent. It enlightens many literary aspects and critical angles. This study revolves around this film, focusing on post-colonialism especially the partition era of 1947. Pierce's Model of Semiotics, as a major framework has been adopted to draw all post-colonial aspects from the film Pinjar.

Keywords: Film Studies, Indian Sub-continent, Post-colonialism, Semiotics, South Asian Cinema 


\section{INTRODUCTION}

Post-colonialism is defined as the study of affiliation between the colonizers and the colonized nations (Laurie, Stark, \& Walker, 2019). Post-colonialism consists of different concepts of feminism, orientalism, history, sociology, human geography, anthropology, political science, linguistics, philosophy, film, architecture, Marxism, theological and religious studies and literature (Shands, 2008). Marxist scholar Vivek Chibber from India presented the logics of postcolonial theory in his book, The Debate on Postcolonial Theory and the Specter of Capital (2013). He focused on the disproved historical claims made by the Subaltern studies scholars like Ranajit Guha. Chibber further argued to make the culture essential in the society (Chibber, 2017). In addition, the theory of post- colonialism presented the difference of the East and the West (Sharp, 2008). Moreover; the colonialism is also termed as the extension of civilization, ideologically justified the self-ascribed racial and cultural superiority of the Western world over the non-Western world. The Western domination remained not only in Africa by France but later expanded to Asia by the Great Britain. The British colonized most of the Asian countries turning them into their colonies. The Indian sub-continent was the biggest British colony in Asia (Thomas, 2014 ) therefore the society of Indian Subcontinent is enriched with the signs of post-colonialism. Later on, these signs of postcolonialism not only became the part of literature, but it also became the part of the cinema and many films of Indian Sub-continent are depicting the post-colonialism.

Amrita Pritam is a renowned writer of Indian Sub-continent and her novel Pinjar is among the important novels in Punjabi language (Dutt, 2005); later this Punjabi novel was adapted into an Urdu film with the same name. Pinjar is among one of the leading films on the partition of Indian Sub-continent, produced by $20^{\text {th }}$ Century Fox in 2003 and directed by Chandraprakash Dwivedi. It depicted a multicultural society and religious contrasts. As a British colony for many centuries, the society of Indian Subcontinent was enriched with many signs of post-colonialism from livelihood, administrative matters, culture as well as language and literature. The partition of Indian Sub-Continent is the central theme of the film Pinjar and various characters in the film symbolize different communities. This is the story of 1947, the partition time of Indian Sub-continent. The main theme of the film focuses on a young Hindu girl Puro, the fiancée of wealthy Ramchand. A young Muslim man Rashid was in love with her and he abducted her. After kidnapping, Puro never liked Rashid though he gave her shelter and respect. One day, she managed to escape but her parents rejected her because her honour was tarnished. In addition, they were living in a Muslim populated area and were afraid to be attacked by the Muslims. She decided to commit suicide but Rashid 
married her though she was never happy. In due days of the year 1947, the partition of Indian Sub-continent was announced and it was divided into India and Pakistan. The family of Puro had already left towards India while family of Ramchand was left in Pakistan. They migrated towards India but were attacked on the way. The sister of Ramchand, Lajjo, married to Trilok, the brother of Puro, was also accompanying them. She was kidnapped by the rioters. Puro knew that a caravan was staying in her village and she decided to visit there. There she found Ramchand and came to know all about her family and Lajjo. She promised Ramchand to search for Lajjo. The next day, she wandered in the whole village as a saleswoman. In one of the homes, she found Lajjo and made her to escape from there. Rashid and Puro took her to the Wagha border where Ramchand and her brother Trilok were waiting for Lajjo. Trilok offered her to go to India with them but she softly denied as she was adjusted in her life now. She replied to Trilok, "Whenever a girl gets back to her family then think that Puro has also rejoined her family." Mr. Amberish K Diwanji reviews the film as, "Pinjar, set in the Partition era of 1947 is about the sad position, women occupied in our society then, and continue to occupy today. Even when she is the victim of a crime, the woman is the one who is blamed. She must pay the penalty so that the family's izzat (honour) is not tainted (Diwanji, 2003). Pinjar is enriched cinematographically and it is having many angles of film semiotics.

Semiotics is the study of signs and sign processes also known as Semiosis (Chandler, 2007 ). This study is related with signs, similarities, analogies, titles, metaphors, significations, symbolism, and communication. Language too, is known as one system of signs. In the ancient times, the signs were used as a language (Frutiger, 1998 ). In old Egyptian or Indus civilization, signs can be found in different caves and mountains, where the human beings passed their lives (Loeffler, 2016). Every colonized society is enriched with the signs and the symbols of post-colonialism therefore Pierce's Model of semiotics has been adapted to analyse the film Pinjar to study the elements of postcolonialism in the society of Indian Sub-continent as portrayed in the cinema.

\section{LITERATURE REVIEW}

According to Said, "You cannot continue to victimize someone else just because you yourself were a victim once-there has to be a limit (Said, 2012). This statement of Said wanted an end of Post Colonialism from one territory to another territory and all those countries went through the process of colonialism should not follow it in future to colonize others. Post-colonialism examines the social and political power relationships to sustain colonialism and neocolonialism, including the social, political and cultural narratives among the colonizers and the colonized nations in science, philosophy, sociology, anthropology and human geography (Loomba, 2007). Both film studies and 
the postcolonial theory emerged at the end of 1970 with the advancement of semiotic theory and poststructuralist thought (Sinnerbrink, 2012). Postcolonial theory initially emerged from comparative literature and film from media studies department. Both disciplines of film studies and the postcolonial theory engaged intensively with the field of representation and the postcolonial theory has significantly contributed in revisiting the representation (Ponzanesi, 2018). It applies new interventions on how visual representations are drawn in policing the boundaries between the East and the West, between Europe and the Rest, the self and the other, rethinking the ways in which the visual field conveys operation of a mastery that needs to be undone and decoded. For example, empire cinema contributed to specific ways of seeing, making films that legitimated the domination of colonies by the colonial powers. Colonial images of gender, race and class carried ideological connotations (Ponzanesi \& Waller, 2012).

The famous scholar Ferdinand de Saussure viewed the semiotics as, "It is probable to envision of a science to study the role of signs as a part of social life. Being a part of social psychology, it would also be the part of general psychology. We shall call it semiology derived from the Greek word semeîon meaning as 'sign'. It would explore the nature of signs and the laws governing them (Kearney, 1996, p. 298). In the $19^{\text {th }}$ century, Charles Sanders Pierce (1839-1914), a prominent logician founded philosophical pragmatism. It is defined as semiosis, an irreducibly triadic method; wherein something, as an object, logically influences something as a sign to determine something as an interpretation or interpretant, itself a sign, thus leading to further interpretants (Bergman \& Paavola, 2003). This article is also analyzing the signs, in the Postcolonial society of the Indian Sub-continent as portrayed in the film Pinjar.

\section{METHODOLOGIES}

This article is taking the approach of qualitative research to study the elements of post-colonialism in the society of Indian Sub-continent as portrayed in the film Pinjar. The main source of data is from the film Pinjar. The analysis of the film focuses on the plot of the story to scrutinize post-colonial signs, inserted in different scenes of the film. This research is conducted by applying the theory of post-colonialism to trace out the postcolonial signs in the society and culture of Indo-Pak Sub-continent, as they lived under British regime for centuries. The Pierce Model of semiotics has been adapted to analyse the film critically to obtain the targeted results. 


\section{ANALYSIS AND DISCUSSION}

This article aims to better understand the impact of post-colonialism in the society of Indian sub-continent as portrayed in the film Pinjar. The timeframe of the film is the partition time of Indian Sub-Continent in 1947. The film covers the life of a playful Hindu girl, Puro kidnapped by a Muslim man Rashid. Though she fled away and reached her home but her parents rejected her because her honour was tarnished. After rejection, Rashid took her back to his home and then married her. Her brother Trilok was yet in her search. He never came to know that she had got back to their home but was rejected by his parents. Therefore, he was trying to get back her sister as well as seeking revenge from Rashid. In this fire of revenge, one day, he burnt the wheat fields of Rashid and everything turned into ashes. The first two figures discussed below are depicting the scene after the burning of the crop.

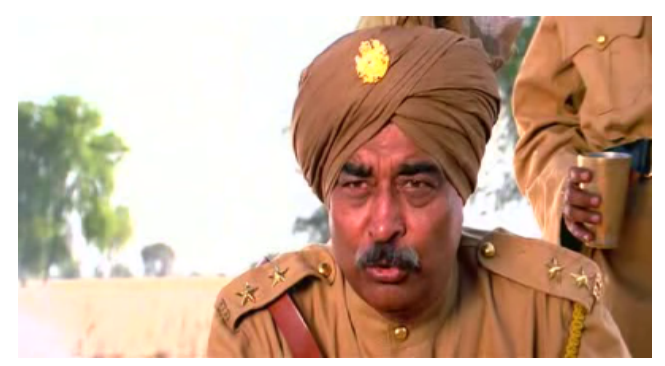

Figure 1: A policeman of Indian Sub-Continent

After the crop was burnt and the case was registered against the unknown culprit, the police visited the spot to investigate the matter. The policemen arrived on the spot of the incident, were the servant of British government as yet the country had not got independence. Therefore, we see in Figure 1, the police officer, known as Daroogha Sahib in Hindi, is wearing a brown uniform. The police officer is also wearing a turban (Patka or Pagrri in Urdu or Hindi language). It's the cultural symbol of the native people of Indian Sub-continent. There are stars on his shoulders and a sign on his turban as the symbols of post-colonialism. The policemen of the British government happened to wear shirts, with shorts along with the boots. In addition, if those wore turban (Patka or Pagrri) then they used the stars or the signs of the British government over it (Indy, 2013). 


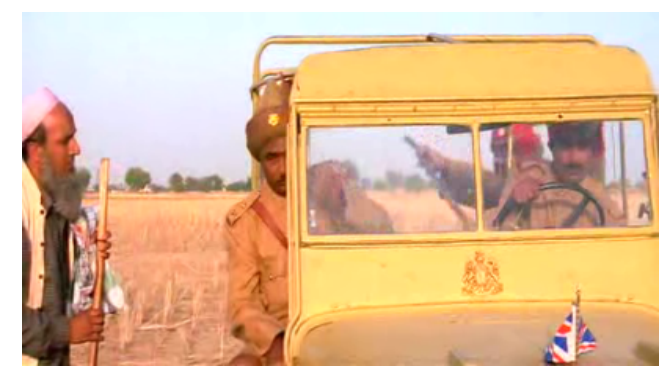

Figure 2: Arrival of police in the burnt fields

Figure 2 is also related to the same scene. A British flag is waving in the front of the jeep, being used by the police officers. It is also known as Union Jack, Union flag or Royal Union flag (Institute, 2020). The flag is termed as the representative of any country, nation or the territory therefore this Union Jack is clearly indicating the postcolonial sign because it's the territory of Indian Sub-continent during the days of partition but yet the flag is that of Great Britain.

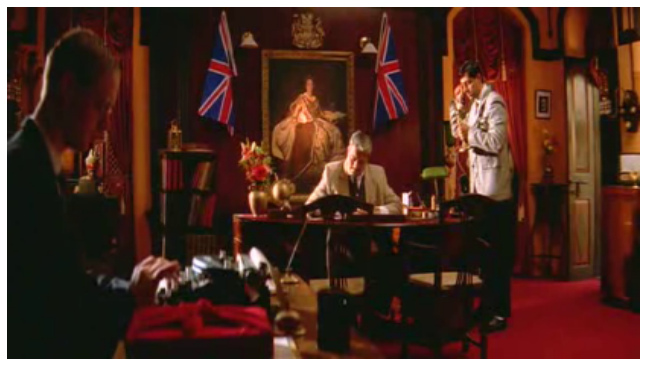

Figure 3: Trilok is calling from a British office

Although, Trilok had sought the revenge by burning the wheat-crop of Rashid but yet his anger was not cooled down. He had also registered a police case though his parents never favoured his act. In Figure 3, Trilok, is calling the police station. He is enquiring about the police report submitted by him, against the protagonist Rashid for abducting his sister Puro. Though she got a chance to run away but was rejected by the parents because of tarnishing her Honour. Trilok was unnoticeable about it and was yet struggling for the return of his sister. In the background of the office, he is calling from; two British flags are traceable. These flags are indicating post-colonialism as the office is located in Indian Sub-continent but the flag, being adorned in the offices is that of British government. 


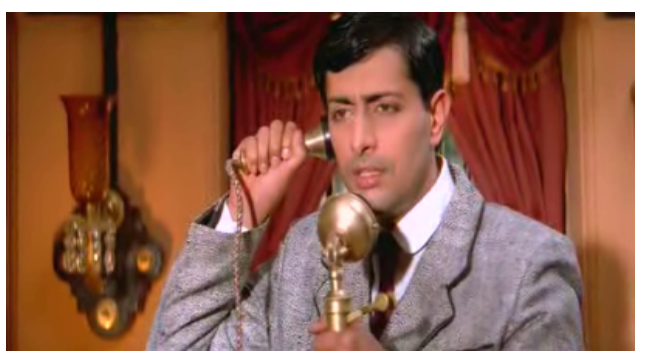

Figure 4: Use of Telecommunication in Forties

Figure 4 is also from the same scene, discussed above. Trilok is talking on a telephone which is a post-colonial sign. Before the arrival of British in the Indian Sub-continent, there was no electronic communication system. The telephone in the era of midnineteenth century after Second World War was only used in the British government offices in the Indian Sub-continent (Huurdeman, 2003 ).

After some months, the parents of Puro married Trilok to Laijo, the younger sister of Ramchand while Ramchand was married to the younger sister of Puro, Rajjo. After marriages, the entire family of Puro shifted to Amritsar. Meanwhile, the partition of Indian Sub-continent was announced by the British government. As the city of Amritsar was included in India, so the family of Puro was secure while the villages of Ramchand and Puro were the part of Pakistan. A week back, Trilok had brought Lajjo at her home. Ramchand, Lajjo and their mother migrated immediately towards India in the burning homes. They joined one of the caravans but in the way the rioters attacked it. They kidnapped Lajjo before the eyes of helpless brother and the mother. Later, Puro found her and then she and her husband took her to the Wagha border where the refugee camp was established for immigrants. (Zaman, 2010).

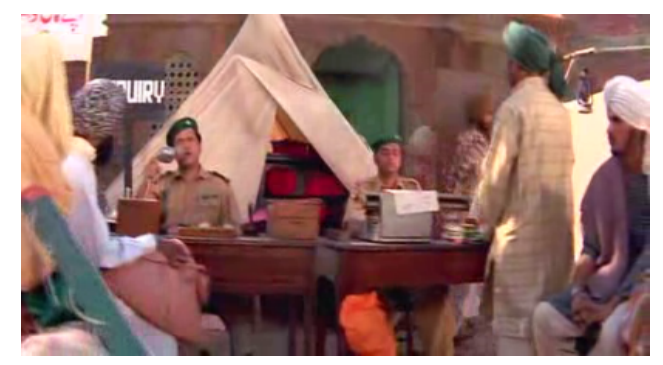

Figure 5: A Refugee camp

In the Figure 5, there is a scene of a refugee camp, after the partition of Indian Subcontinent. Many such camps were established for immigrants from various areas of both India and Pakistan. This camp is located on the Wagha border in Lahore. It is the scene when Puro and her husband had gone to handle Lajjo to Trilok. The dutiful people, advising the people about new countries, are wearing green caps indicating 
them from Pakistan but the board behind the one soldier is in English language. The area in the scene is that of Pakistan but yet the language is that of colonizers.

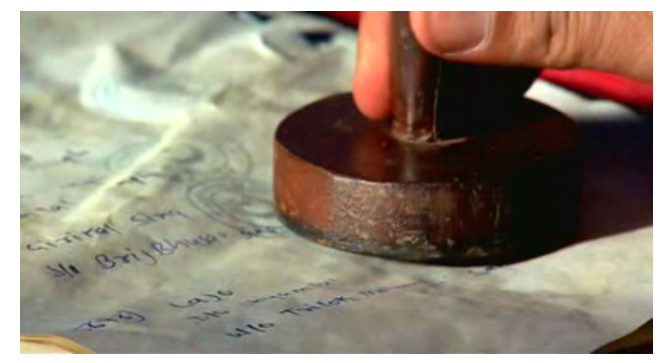

Figure 6: A document in an office

The Figure 6 is also from the very next few scenes of the film. It is also from the refugee camp where a stamp is being used. The piece of paper is in English language, seems to be any government order or an application. According to Anna Corrad, "Until the 19th century, the British were the major superpower, and their method of colonization included establishing schools which taught English language and Western culture to locals who needed to be "modernized (Corrad, 2017)." Therefore the English language in this application is merely a post-colonial sign.

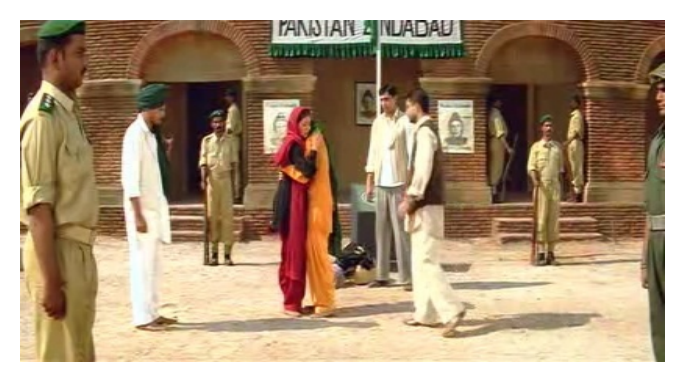

Figure 7: The departing moment at Refugee's Camp

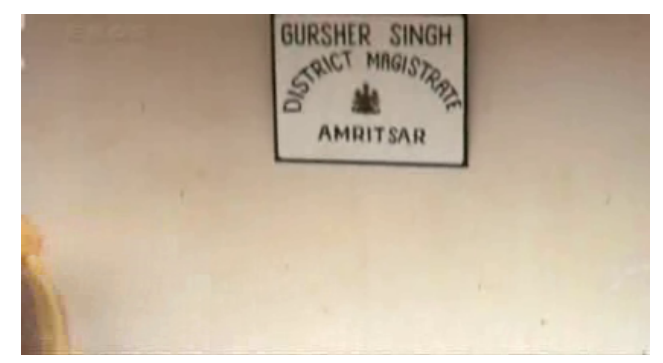

Figure 8: An office of District Magistrate

The end of the film happened in the refugee camp and Figure 7 and 8 are from the last scenes of the film. The situation in these figures is not different from that of Figure 6. According to Anna Corrad, "Most former British colonies now use English as their 
official language e.g. Ghana and South Africa (Corrad, 2017)." As like Ghana and South Africa, Indian Sub-continent also stayed a complete British colony from 1857 to 1947. It was the reason that the English language got a permanent place in the society of Indian Sub-continent therefore in the Figure 7, a banner is fixed on the wall on which instead of Urdu, Pakistan Zindabad is written in English language while in the Figure 8, the board outside the magistrate office is also printed in English language. Though the area portrayed in the film in that of Lahore, Pakistan but yet the society was having the post-colonial elements because English was an official language of Indian Subcontinent during the British regime.

\section{CONCLUSION}

This article has sought to provide an account of the post-colonial signs depicted in the film Pinjar. Through an analysis of the film, the article highlighted the elements of postcolonialism with a focus on the linguistics and the administrative domination of the British colonizers over the colonized nation of Indian Sub-continent. This study focused on the post-colonial signs of the British regime from the society of Indian sub-continent to the representation in the Bollywood cinema. Future researchers are encouraged to analyse this film according to other theory and framework to contribute more academic research in the field of cinematography. 


\section{REFERENCES}

1. Bergman, M., \& Paavola, S. (2003,). The Commens Dictionary of Pierce's Terms. Retrieved 04 04, 2012, from Commens: http://www.helsinki.fi/science/commens/dictionary.html

2. Chandler, D. (2007). Semiotics: The Basics. London: Routledge.

3. Chibber, V. (2017). The Debate on Postcolonial Theory and the Specter of Capital. New York: Verso.

4. Corrad, A. (2017). The Linguistic Colonialism of English. Retrieved 05 01, 2020, from Brown Political Review : http://brownpoliticalreview.org/2017/04/linguisticcolonialism-english/

5. Diwanji, A. K. (2003). Pinjar is a must-see. Retrieved from rediff.com: https://www.rediff.com/movies/2003/oct/23pinjar.htm

6. Dutt, N. (2005). Pinjar: A Novel Ahead of its Times. Retrieved from The Tribune: https://www.tribuneindia.com/2005/20050220/spectrum/book3.htm

7. Frutiger, A. (1998). Signs and Symbols: Their Design and Meaning. New York: Watson-Guptill Publications.

8. Huurdeman, A. A. (2003). The Worldwide History of Telecommunications. New Jersey: John Wiley \& Sons. From WayBack Machine.

9. Indy (2013). Take Me on a Trip a Long, Long Time Ago! Retrieved 2020 йил 0605 from Tumblr: https://indypendenthistory.tumblr.com/post/64112385219/1940military-police-of-the-indian-army-lined-up

10. Institute, F. (2020). Union Jack or Union Flag? Retrieved 05 10, 2020, from Flag Institute: https://www.flaginstitute.org/wp/british-flags-2/the-union-jack-or-theunion-flag/

11. Kearney, R. (1996). The Continental Philosophy Reader. London: Psychology Press.

12. Laurie, T., Stark, H., \& Walker, A. (2019). Critical Approaches to Continental Philosophy: Intellectual Community, Disciplinary Identity, and the Politics of Inclusion. A Journal of Critical Philosophy, 1-17.

13. Liddell, H. G., \& Scott, R. (2007). A Greek-English Lexicon. London: Simon Wallenberg Press.

14. Loeffler, H. (2016). Introductory Guide to Ancient Civilizations. New York: CreateSpace.

15. Loomba, A. (2007). Colonialism/Postcolonialism. London: Routledge.

16. Murray, J. (2006). Locke's Essay on the Human Understanding. Oxford: Oxford University Press.

17. Nöth, W. (1995). Handbook of Semiotics. Indiana : Indiana University Press.

18. Ponzanesi, S. (2018). Postcolonial Theory in Film. Retrieved 2020 йил 05-05 from Oxford Bibligraphies : https://www.oxfordbibliographies.com/view/document/obo-9780199791286/obo9780199791286-0284.xml

19. Ponzanesi, S., \& Waller, M. (2012). Postcolonial Cinema Studies. London: Routledge.

20. Said, E. W. (1979). Orientalism. UK: Knopf Doubleday Publishing Group.

21. Said, E. W. (2012). Quotes of Edward Said. Retrieved 02 13, 2014, from Goodreads: www.goodreads.com/author/quotes/24390.Edward_W_Said 
22. Shands, K. W. (2008). Neither East Nor West . Stockholm : Södertörns högskola.

23. Sharp, J. (2008). Geographies of Postcolonialism. UK: SAGE.

24. Sinnerbrink, R. (2012). Sea-Change: Transforming the 'Crisis' in Film. MEDIA/REP, 67-84.

25. Thomas, M. (2014). Fight or Flight: Britain, France, and their Roads from Empire. Oxford: Oxford University Press.

26. Zaman, F. (2010). Adabiyaat: Amrita Pritam Number. Islamabad: Pakistan Academy of Letters. 